\title{
DESEMPENHO ECONÔMICO-FINANCEIRO DE INDÚSTRIAS CALÇADISTAS BRASILEIRAS: UMA ANÁLISE DO PERÍODO DE 2000 A 2006
}

\section{ECONOMIC-FINANCIAL PERFORMANCE OF BRAZILIAN FOOTWEAR INDUSTRIES: AN ANALYSIS OF THE PERIOD FROM 2000 TO 2006}

\author{
ADRIANO JOSÉ AZEREDO \\ Mestre em Ciências Contábeis pela \\ Universidade do Vale do Rio dos Sinos \\ Professor do Centro de Gestão Organizacional do \\ Centro Universitário Univates \\ Lajeado/RS, Brasil \\ E-mail: adrianoj@univates.br
}

\author{
MARCOS ANTONIO DE SOUZA \\ Doutor em Controladoria e Contabilidade pela \\ Universidade de São Paulo \\ Professor Titular do Centro de Ciências Econômicas da \\ Universidade do Vale do Rio dos Sinos \\ São Leopoldo/RS, Brasil \\ E-mail: marcosas@unisinos.br
}

\author{
DÉBORA GOMES MACHADO \\ Mestre em Ciências Contábeis pela \\ Universidade do Vale do Rio dos Sinos \\ Professora Assistente do Instituto de Ciências \\ Econômicas, Administrativas e Contábeis da \\ Universidade Federal do Rio Grande \\ Rio Grande/RS, Brasil \\ E-mail: debora_furg@yahoo.com.br
}

Resumo

O objetivo do estudo é avaliar o desempenho econômico e financeiro de empresas do segmento calçadista brasileiro, de forma a produzir informações úteis às decisões dos respectivos usuários. Caracteriza-se o ambiente do segmento a partir da década de 1980, quando o mercado competitivo passou a exigir mais qualidade na gestão das atividades. Nesse contexto, a contabilidade é vista como uma das fontes de informações necessárias à utilização eficaz de recursos. Trata-se de uma pesquisa de natureza exploratória, documental e quantitativa. Foram coletados dados das demonstrações contábeis publicadas, correspondentes aos exercícios de 2000 a 2006, e relativas a 15 indústrias do segmento. A utilização de 30 indicadores possibilitou a análise do conjunto das empresas, por meio de índicespadrão. 0 ranking dessas empresas baseou-se na metodologia aplicada pela publicação da revista Exame Melhores e Maiores. Os principais resultados da análise indicam estabilidade na liquidez, melhora nos índices de solvência e redução do endividamento de curto prazo. A atividade operacional apresenta queda nas vendas líquidas e aumento nos prazos médios de estocagem e de recebimento de clientes. Houve redução nas margens de lucratividade e de rentabilidade reflexo, também, na queda no giro dos ativos. A recuperação dos prejuízos operacionais se deu em função dos ganhos no mercado financeiro. No ranking do período, as empresas Dilly Nordeste e São Paulo Alpargatas apresentam-se em $1^{\circ}$ e $2^{\circ}$ lugares, respectivamente.

Palavras-chave: demonstrações contábeis; análise econômico-financeira; índice-padrão; ranking de empresas.

\begin{abstract}
This study aims to evaluate the economic and financial performance of Footwear Brazilian industry, resulting in useful information to professionals of this area to take decisions. The environment of the segment is characterized since the decade of 1980, when the competitive market started to demand more quality in the management activities. In this context, the accounting is seen as one of the sources of necessary information to the efficient use of resources. It is an exploratory and documental research, whose data were analyzed under quantitative approach. The data were obtained from financial statements published, corresponding to the period from 2000 to 2006, and involving 15 industries. The use of 30 indicators made it possible to analyze the companies, by means of index-standards. The ranking of the companies was based on the methodology applied by Exame Melhores $e$ Melhores magazine. The main results appointed stability in the liquidity, improvement in the solvency and short term indebtedness ratios. The operational activity presents fall in the net sales and increase in the average level of inventories and day sales outstanding. As a partial consequence of the fall in the assets turn-over level, it was identified a reduction in profitability margins. The operational damages recovery was given in function of the profits in the financial market investments. In the ranking of the period, the companies Dilly Nordeste and São Paulo Alpargatas are present in first and second places, respectively.
\end{abstract}

Key words: financial statements, economic and financial analysis, standards-index, ranking of companies. 


\section{INTRODUÇÃO}

O conhecimento da origem e da razão das transformações da riqueza deve estar apoiado em um critério analítico e competente para produzir modelos de comportamentos de prosperidade (MOSIMANN\& FISCH, 1999). Nesse sentido, uma das técnicas utilizadas pela contabilidade no estudo da evolução patrimonial das empresas é a análise das demonstrações contábeis, a qual se vale de indicadores do desempenho econômicofinanceiro das empresas. Tais informações possibilitam estabelecer modelos de orientação para a tomada de decisão pelos diferentes usuários das informações contábeis, por meio da confecção de relatórios que contenham informações destinadas a atender o interesse específico de cada grupo.

Os indicadores podem ser apurados por empresa ou mediante o auxílio da técnica de índices-padrão, conforme enfatizam Assaf Neto (2006), Matarazzo (2003) e Silva (1995), fazer a comparabilidade dos índices econômico-financeiros de uma empresa em relação aos de outras, das empresas em relação ao setor ou ainda entre empresas de diversos ramos de atividade. 0 índice-padrão é um referencial para a comparação de índices da empresa com padrões internos, preestabelecidos pela direção da organização como metas almejadas. Já sob o aspecto da análise setorial, consiste na apreciação macroeconômica em relação a determinado setor da economia, auxiliando no posicionamento das principais empresas atuantes no segmento pesquisado.

Exemplo do uso dessa técnica são as diversas publicações de ranking existentes no Brasil e no exterior que, após a apuração dos índices-padrão, classificam as empresas segundo o peso atribuído a cada indicador calculado. Melhores e Maiores (Exame), Balanço Anual (Gazeta Mercantil), Valor 1000 (Valor Econômico) e Fortune 500 são algumas dessas publicações.

O setor calçadista é um dos vários segmentos empresariais de relevância econômica nacional que fazem uso da análise das demonstrações contábeis. As pesquisas de Schneider (2003) e Gianisella (2006) evidenciam o uso que esse segmento faz de indicadores econômico-financeiros extraídos das demonstrações contábeis para a medição do seu desempenho. $O$ enfoque na busca pela otimização desse desempenho pressupõe a necessidade da empresa em conhecer um conjunto de indicadores, inclusive os de natureza econômica e financeira, que permitam examinar sua situação no período desejado e gerar informações para o processo de tomada de decisão dos usuários interessados.

Nesse contexto, o objetivo geral do estudo concentra-se em diagnosticar o desempenho econômico-financeiro de indústrias calçadistas brasileiras, relativamente ao período de 2000 a 2006. Paralelamente a esse diagnóstico, se disponibiliza um conjunto de informações, no formato de indicadores e da interpretação do seu significado, úteis ao processo decisório dos respectivos usuários, sejam eles internos ou externos às empresas. O período selecionado contempla um maior número de demonstrações publicadas e possibilita a análise de desempenho no âmbito de períodos de moeda interna valorizada e desvalorizada perante o dólar norte-americano, dos reflexos da concorrência chinesa, de relativa estabilidade econômica nacional, dentre outras conjunturais.

Dada a representatividade do segmento calçadista na economia regional e nacional, tendo em vista a sua importância como atividade econômica e social, considera-se relevante retratar, com base na amostra selecionada, o desempenho econômico-financeiro desse setor. Destaca-se, ainda, que o segmento calçadista caracteriza-se, pela própria natureza societária da grande maioria das empresas que o compõem (sociedades limitadas ou sociedades anônimas fechadas), de reduzida disponibilidade ao mercado de informações como as apresentadas nesse estudo. 


\section{REFERENCIAL TEÓRICO}

\subsection{ASPECTOS GERAIS DO SETOR CALÇADISTA BRASILEIRO}

A indústria calçadista, conforme destacado por Schuh (2006), apresenta interrelações com diversos setores industriais, destacando-se a indústria química e do vestuário, porém, seus segmentos mais importantes estão relacionados ao processamento do couro e à confecção do calçado. A cadeia coureiro-calçadista é descrita na Figura 1.

Ainda de acordo Schuh (2006), em 2004 a indústria brasileira de calçados era formada majoritariamente ( $75 \%$ do total) por empresas classificadas como microempresas (até 19 empregados); as de pequeno porte (de 20 a 99 empregados) correspondiam a 18\%; $5 \%$ como médias empresas (de 100 a 499 empregados), e apenas $2 \%$ como grandes empresas (500 ou mais empregados).

Em 2005, conforme estudo de Forte e Moreira (2007) e dados da Associação Brasileira das Indústrias de Calçados - ABICALÇADOS (2007), o parque calçadista nacional era formado por cerca de 9 mil indústrias, as quais geravam cerca de 299 mil empregos diretos. Encontravam-se instaladas em quase todo território brasileiro, com destaque para os estados do Rio Grande do Sul, São Paulo, Ceará, Bahia e Pernambuco, além de Santa Catarina e Minas Gerais. Destes, o principal estado produtor de calçados ainda é o Rio Grande do Sul, com empresas de faturamento anual entre US\$ 10 e 50 milhões.

Em 2006, o setor produziu cerca de 800 milhões de pares de calçados, sendo $77 \%$ deles destinados ao mercado interno. Os principais tipos de calçados exportados foram: 49\% de couro, $41 \%$ de plástico, $7 \%$ de material têxtil e 3\% de outros materiais (ABICALÇADOS, 2007). O faturamento anual estimado do setor calçadista brasileiro, conforme Caetano (2008) situa-se em R\$ 20 bilhões.

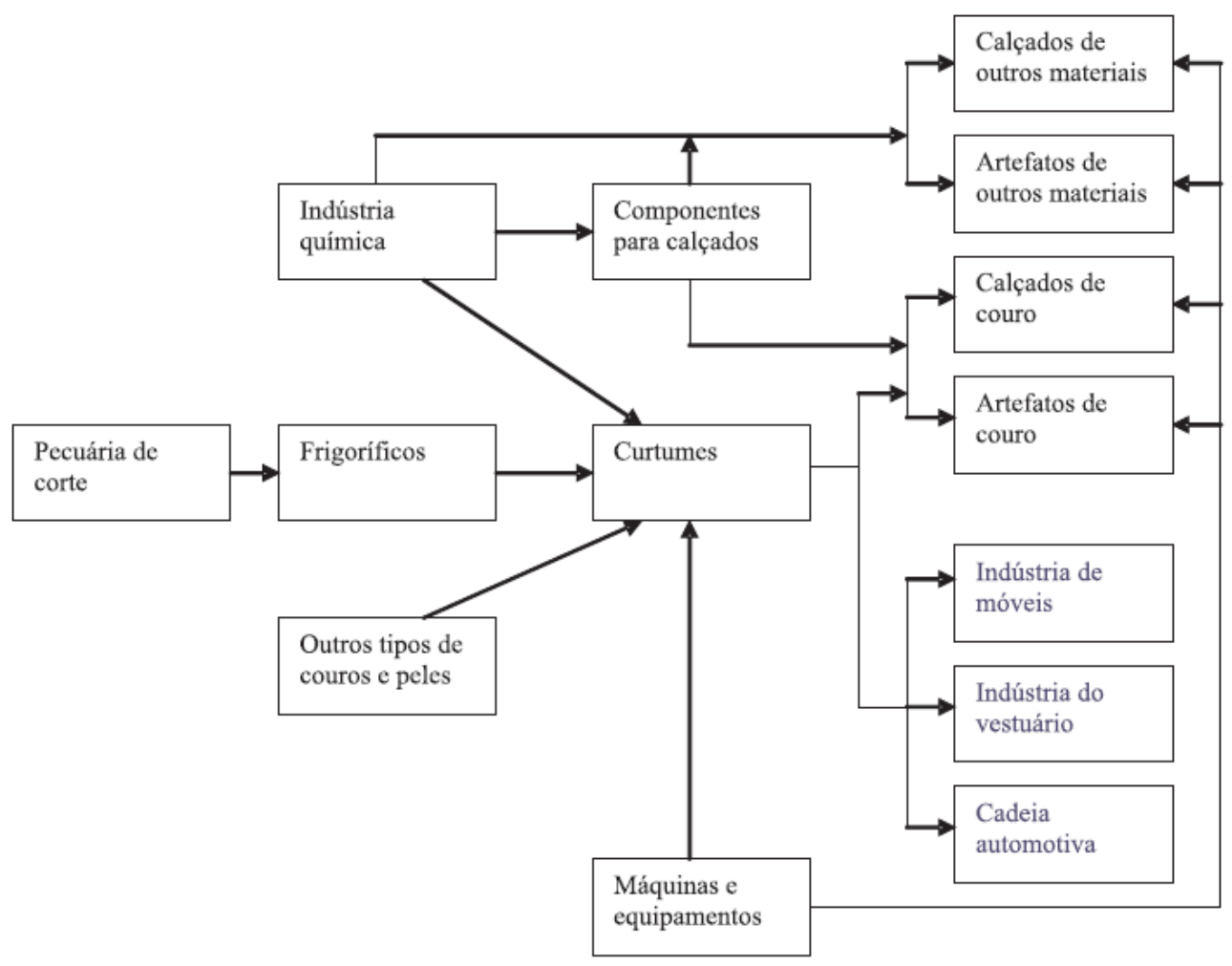

Figura 1: Descrição básica da cadeia coureiro-calçadista Fonte: Carloni; Costa \& Garcia (2007) 
A exportação da produção brasileira destina-se a mais de 140 países. Dados da ABICALÇADOS (2007) revelam que os principais importadores, em relação ao volume, são: Estados Unidos (36\%), Reino Unido (6\%) e Argentina (12\%). Quanto ao faturamento gerado pela exportação, esses três países são responsáveis por $46 \%, 11 \%$ e $7 \%$, respectivamente, ou seja, 64\% das exportações brasileiras.

Em um contexto estrutural, entende-se que essa atuação no mercado externo tem uma relação direta de dependência com as questões relacionadas à política cambial. Barbosa e Alvim (2006) constataram em seu estudo, realizado com base no comportamento das exportações do Rio Grande do Sul, que a desvalorização do Real influencia diretamente na elevação do valor das exportações brasileiras de calçados (em Reais), e vice-versa quando há elevação nos preços médios em dólar.

Estudo do Banco Nacional de Desenvolvimento Econômico e Social - BNDES (2006) observa que, de fato, a política cambial afeta a competitividade do setor calçadista brasileiro no mercado internacional, acirrando, ainda mais, a concorrência com os produtos chineses. Corroborando os dados do BNDES, as estatísticas da ABICALÇADOS (2007) apresentam o expressivo crescimento das exportações dos países asiáticos ao mercado norte-americano. Em contrapartida, há redução brasileira (cerca de $73 \%$ ) no volume de pares negociados em 2006. Além do crescimento das importações de calçados chineses pelos Estados Unidos, as exportações chinesas para a Europa aumentaram 9,8\% nos primeiros dez meses do ano de 2007, em relação ao mesmo período do ano de 2006 (ASSINTECAL, 2007).

0 aumento das concorrências externa e interna forçou as grandes empresas calçadistas das regiões Sul e Sudeste, a partir da década de 1990, a deslocarem unidades fabris para o Nordeste brasileiro, em busca de menores custos de produção, transporte e mão-de-obra, além da fruição dos incentivos fiscais oferecidos pelos governos estaduais daquela região, almejando maior competitividade e maior participação no mercado internacional.

A localização da região Nordeste, em relação aos Estados Unidos, também influenciou o deslocamento, embora as grandes empresas tenham mantido nas regiões tradicionais suas funções corporativas superiores, como o desenvolvimento de produtos (SANTOS et al., 2002; BNDES, 2006; CARLONI; COSTA \& GARCIA, 2007; VIANA \& ROCHA, 2006). Além disso, ocorreram processos de internacionalização das empresas e um maior enfoque ao mercado interno. Outras empresas fecharam suas fábricas ou reduziram o nível de atividade ou, ainda, procuraram elevar suas vendas para países onde não é verificada a presença dos grandes compradores globais, e que permitiram a reprodução de esquemas de comercialização e distribuição utilizados no mercado doméstico. É o caso da Argentina, Paraguai, Chile, Peru e Bolívia (GARCIA, 2006).

Um caminho utilizado pelas empresas brasileiras para obter maiores ganhos em eficiência, tem sido o crescimento mediante a compra de empresas menores. Como exemplos podem ser citados: a compra da Companhia Brasileira de Sandálias (CBS) pela São Paulo Alpargatas, maior empresa brasileira fabricante de calçados (FOLHA ONLINE, 2007), e a compra da Azaléia pela Vulcabrás (CARVALHO, 2007).

Outra estratégia adotada, como forma de enfrentar a concorrência asiática, é a tendência para produção de calçados com maior valor agregado. Segundo matéria do Jornal Zero Hora (2008), no ano de 2007, apesar da valorização do Real, houve um aumento de $4 \%$ no valor exportado em relação ao ano anterior, em contrapartida à redução no volume de pares embarcados, na ordem de $1,4 \%$. Ou seja, registrou-se um aumento de faturamento com redução do volume. 


\subsection{AVALIAÇÃO DE DESEMPENHO}

A avaliação de desempenho é o processo que permite à empresa uma análise comparativa entre os resultados planejados e os resultados efetivos. É comum, nesse processo, a utilização de padrões preestabelecidos, sejam eles de natureza financeira e/ou não-financeira. A Figura 2 ilustra como a avaliação de desempenho, no âmbito do processo de gestão, abastece a empresa com informações para a tomada de decisões.

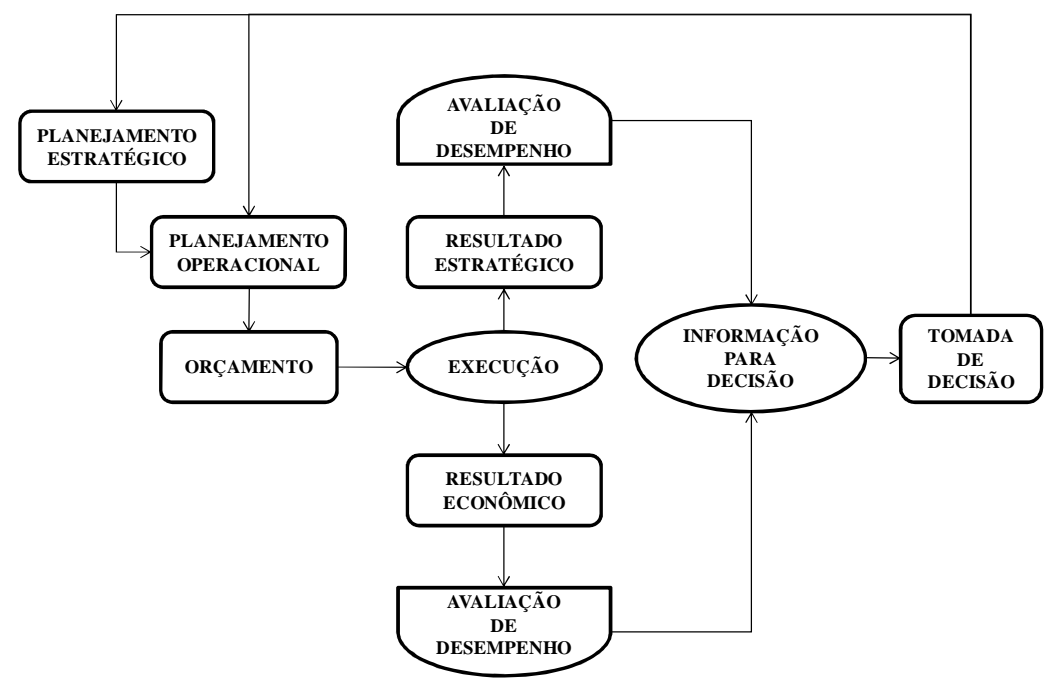

Figura 2: Avaliação de desempenho no processo de gestão Fonte: Adaptado de Aquino \& Tachibana (1999).

De modo geral, o processo de avaliação de desempenho enseja alguns prérequisitos, tais como: (1) definição do que medir; (2) escolha do conjunto de indicadores para saber como medir; (3) desenvolvimento de padrões de comparação; (4) mensuração do conjunto de indicadores;(5) comparação dos dados coletados com os padrões préestabelecidos; (6) análise das informações para a tomada de decisão (PEREIRA, 1999; SCHNEIDER, 2003; MARTINS, 2004). A Figura 3 ilustra o processo de avaliação de desempenho.

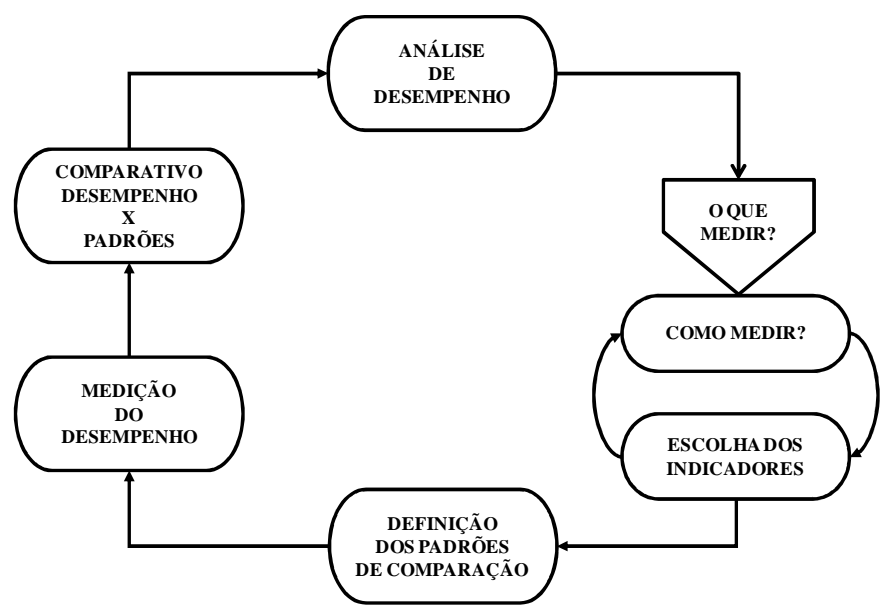

Figura 3: 0 processo de avaliação de desempenho

Fonte: Elaborada a partir de Pereira (1999), Schneider (2003) e Martins (2004). 
De acordo com a necessidade de avaliação de desempenho, podem ser utilizados indicadores financeiros e não-financeiros. Os indicadores financeiros têm sua origem na contabilidade financeira e nos seus sistemas auxiliares, além dos sistemas de custos. Esses indicadores apresentam informações calculadas a partir de dados históricos, utilizados como referência. Por se tratar de dados passados, Berton (2003) ressalva que estes indicadores devem ser utilizados em conjunto com outros. Os indicadores não-financeiros, segundo Miranda e Azevedo (2000), independem da contabilidade da empresa e se referem, por exemplo, aos clientes, à participação de mercado, aos funcionários, entre outros. Martin (1997) descreve que esses indicadores focam os objetivos estratégicos da empresa do menor ao maior nível organizacional. A Figura 4 apresenta as diferentes necessidades de indicadores de cada nível.

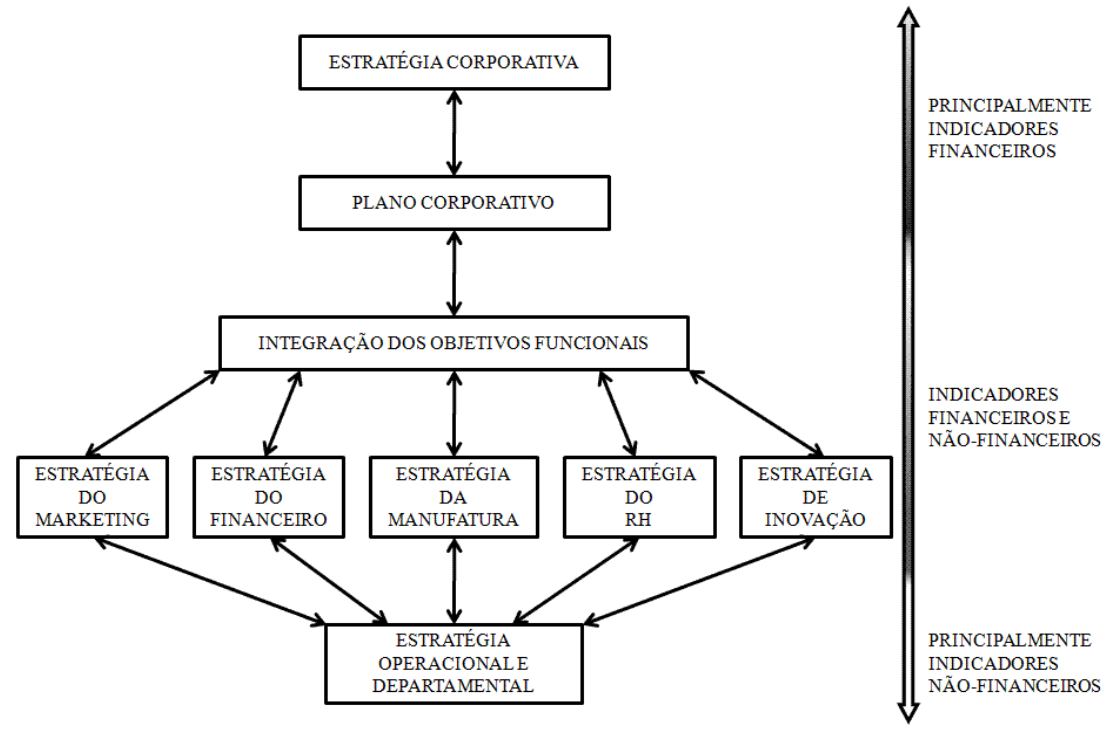

Figura 4: Diferentes necessidades de indicadores Fonte: Adaptado de Martin (1997).

\subsection{ANÁLISE DAS DEMONSTRAÇÕES CONTÁBEIS}

A análise das demonstrações contábeis surgiu e se desenvolveu no sistema bancário norte-americano, em meados da década de 1890. De acordo com Matarazzo (2003), a análise horizontal, como hoje é conhecida, foi iniciada por Stephen Gilman, em 1925. Já a análise do ROI (return on investment) teve seu começo na década de 1930, dentro da empresa DuPont.

Castro Junior (2003) enfatiza que, em 1932, Fitz Patrick desenvolveu o que se conhece como primeiro estudo sobre solvência e insolvência de empresas. Mário (2002) acrescenta que, desde então, muitos outros estudos foram desenvolvidos para avaliar a capacidade de prever problemas financeiros em empresas, a partir de indicadores econômico-financeiros calculados com base nas demonstrações contábeis.

No Brasil, a análise das demonstrações contábeis se difundiu na década de 1970, quando a empresa SERASA passou a operar como central de análise de demonstrações para os bancos comerciais (MATARAZZO, 2003).

As demonstrações contábeis são elaboradas de acordo com critérios que nem sempre se prestaram para fins de análises. Isso implica a necessidade de uma adequação destas ao processo de cálculo dos indicadores econômico-financeiros e da análise de desempenho. Por exemplo, para a comparabilidade entre os períodos é prudente a atualização dos valores para uma mesma data. Além disso, faz-se necessário padronizar as 
demonstrações contábeis com o intuito de atribuir uniformidade a elas, reclassificando-se determinadas contas e evitando que a falta de padrões para a comparação comprometa a qualidade da análise, o que pode deixar as afirmativas sem elementos de referência (ASSAF NETO, 2006; MATARAZZO, 2003).

Matarazzo (2003) discorre, ainda, que, de posse das demonstrações contábeis padronizadas, aplica-se o seguinte raciocínio científico para o processo de análise: (1) extraem-se índices das demonstrações contábeis; (2) comparam-se os índices com os padrões; (3) ponderam-se as diferentes informações e chega-se a um diagnóstico ou conclusões; (4) tomam-se decisões. Os índices evidenciam a relação entre contas ou grupo de contas das demonstrações contábeis que servem de medida, e visam evidenciar determinado aspecto da situação econômico-financeira da empresa, fornecendo uma visão ampla desta situação.

Além desse raciocínio científico, Matarazzo (2003) apresenta uma distinção entre os conceitos de resultado econômico e resultado financeiro. De acordo com o autor, o resultado econômico diz respeito ao lucro ou prejuízo e aumenta ou reduz o patrimônio líquido, mas não necessariamente altera as disponibilidades de dinheiro. No sentido dinâmico, o resultado econômico se refere à formação do lucro líquido e, no sentido estático, se refere ao patrimônio líquido. Já o resultado financeiro refere-se às disponibilidades, representando, de forma dinâmica, a variação do saldo de caixa e, de forma estática, o saldo de caixa. Enquanto no sentido amplo o resultado financeiro referese ao capital circulante líquido, no sentido restrito refere-se ao caixa propriamente dito (Quadro 1).

\begin{tabular}{|c|c|c|c|}
\hline & \multirow{2}{*}{ Econômico } & \multicolumn{2}{|c|}{ Financeiro } \\
\hline & & Amplo & Restrito \\
\hline Estaticamente & Patrimônio líquido & Capital circulante líquido & Saldo de caixa \\
\hline Dinamicamente & Lucro Líquido & $\begin{array}{c}\text { Variação do capital circulante } \\
\text { líquido }\end{array}$ & Variação do saldo de caixa \\
\hline Localização & $\begin{array}{c}\text { Balanço Patrimonial; } \\
\text { Demonstração dos Resultados } \\
\text { do Exercício }\end{array}$ & $\begin{array}{c}\text { Demonstração das Origens e } \\
\text { Aplicações de Recursos }\end{array}$ & $\begin{array}{c}\text { Demonstração dos Fluxos de } \\
\text { Caixa }\end{array}$ \\
\hline
\end{tabular}

Quadro 1: Resultado econômico e financeiro e demonstrações contábeis correspondentes Fonte: Adaptado de Matarazzo (2003).

Em síntese, a análise de desempenho requer cuidados com o intuito de evitar vieses nas conclusões sobre a situação econômico-financeira de determinada empresa ou grupo de empresas. A leitura na íntegra dos relatórios contábeis, a escolha dos índices de correção de valores, a padronização das demonstrações contábeis e a escolha dos indicadores econômico-financeiros podem ser citados como exemplos de alguns desses cuidados. Deve ser levado em conta, também, a necessidade dos usuários (internos e/ou externos à empresa), e a possibilidade de que a análise possa ser realizada somente de posse das demonstrações contábeis publicadas ou dessas complementadas por informações internas da empresa.

\section{4 ÍNDICES-PADRÃO}

A técnica de análise de índices-padrão ganhou destaque a partir de 1931, quando a empresa Dun \& Bradstreet passou a elaborar e divulgar, nos Estados Unidos, índices-padrão para diversos ramos de atividades (MATARAZZO, 2003). A esse respeito, Castro Júnior (2003) e Mário (2002) destacam que, em 1932, foi publicado um estudo inovador 
desenvolvido por Fitz Patrick, relativo ao período de 1920 a 1929, baseado na comparação de índices de 19 empresas solventes e 19 insolventes selecionadas aleatoriamente.

Matarazzo (2003) complementa que a análise das demonstrações contábeis por meio de índices adquire consistência e objetividade quando os índices são comparados com padrões. Marion (2005) comenta que, sem os índices-padrão, a conceituação dos indicadores torna-se um grande malabarismo. Porém, a fim de evitarem-se deduções equivocadas, Assaf Neto (2006, p. 284) destaca a necessidade de reconhecer-se que "a técnica de análise por meio de índices, apresenta uma limitação metodológica derivada do fato de cada indicador ser avaliado de forma isolada". Levar esse aspecto em consideração, segundo o autor, concede maior qualidade aos trabalhos de análise.

Considerados esses fatos, pode-se distinguir a avaliação dos índices, de acordo com os seguintes aspectos destacados por Matarazzo (2003):

- pelo significado intrínseco: limitada aos índices da própria empresa e utilizada somente quando não se dispõe de índices-padrão de um conjunto de empresas;

- comparação ao longo de vários exercícios; evidencia as tendências da empresa no tempo;

- comparação com padrões; permite a comparação dos índices da empresa analisada com padrões extraídos da análise de um conjunto de empresas afins.

Ao discorrer sobre a técnica de elaboração de índices-padrão, Assaf Neto (2006) e Matarazzo (2003) enfatizam que decis e quartis são medidas que também possibilitam apurar um valor-padrão representativo da distribuição. A distribuição dos índices em quartis consiste em dividi-los em quatro partes iguais, atribuindo a cada classe $25 \%$ da amostra, possibilitando três medidas de posição. Desta forma, no $2^{\circ}$ quartil (mediana) encontra-se o valor que terá $50 \%$ dos índices abaixo de si mesmo e que está abaixo de $50 \%$ dos demais índices.

A aplicação dos índices-padrão é ilustrada por Assaf Neto (2006), que sugere o critério de análise comparativa, conforme o Quadro 2:

\begin{tabular}{|l|c|c|c|c|c|}
\multicolumn{1}{c|}{ Quartil } & \multicolumn{1}{c}{$1^{\circ}$} & $2^{\circ}$ & Mediana & $3^{\circ}$ & $4^{\circ}$ \\
\hline Qundice & Insatisfatório & Regular: Normal & Bom & Excelente \\
\hline Quanto menor, melhor & Excelente & Bom & Normal Regular & Insatisfatório \\
\hline
\end{tabular}

Quadro 2: Exemplo de critério de análise comparativa com quartis

Fonte: adaptado de Assaf Neto (2006).

Como forma de confrontar a mediana, Vertes e Würch (1986, p. 265) destacam que, nos países desenvolvidos, estabelece-se um valor médio dos coeficientes calculados num conjunto de empresas do mesmo ramo de atividade denominado valores típicos, e argumentam que eles “[...] não são valores ideais ou valores excelentes desejados, mas são coeficientes médios característicos num certo período para um certo ramo de atividade". 


\section{CLASSIFICAÇÃO E PROCEDIMENTOS METODOLÓGICOS}

\subsection{CLASSIFICAÇÃO DA PESQUISA}

Essa pesquisa analisa o desempenho econômico-financeiro de empresas integrantes do setor calçadista brasileiro, extraindo, em seguida, um perfil do conjunto destas empresas e confrontando-o com as análises individuais. Sendo assim, e com base nos critérios apresentados por Gil (2002) e Beuren (2003), a pesquisa coloca a generalização como um produto posterior, buscando, primeiro, comparar o desempenho individual de cada empresa com as demais, ou com o desempenho do conjunto de empresas analisadas. Ela se identifica, portanto, com o método comparativo.

Além disso, dado que ela gera conhecimentos para a aplicação prática, utilizandose de técnicas estatísticas, ela é classificada, quanto à natureza, como pesquisa aplicada e, quanto à abordagem, como quantitativa. Em relação aos objetivos, a pesquisa é descritiva (cria um perfil de um grupo de eventos). Já com relação aos procedimentos técnicos, ela é documental, dado que se vale de materiais (as demonstrações contábeis) que não receberam ainda tratamento analítico ou que podem ser re-elaborados de acordo com os objetivos da pesquisa (GIL, 2002; BEUREN, 2003).

\subsection{AMOSTRA DA PESQUISA}

A população da pesquisa é composta por empresas integrantes do setor calçadista brasileiro que publicam suas demonstrações contábeis. A identificação da população tem como base inicial o cadastro publicado em 2007 pela ABICALÇADOS, com 161 fabricantes. Da lista de fabricantes encontrou-se uma população de 27 empresas.

Utilizando a amostragem por tipicidade ou intencional, foram selecionadas 15 empresas, identificadas como empresas que publicaram as demonstrações contábeis durante todo o período de 2000 a 2006. Essa amostra (Quadro 3) destaca-se por sua importância no setor. De fato, em 2006, o faturamento bruto deste grupo de indústrias resultou no montante de $\mathrm{R} \$ 5,14$ bilhões, representando, aproximadamente, $26 \%$ do faturamento anual do setor, estimado, conforme Caetano (2008), em R\$ 20 bilhões. Compõe a amostra cinco empresas de capital aberto - Azaléia, Cambuci, Grendene, Alpargatas e Vulcabrás - listadas na Bolsa de Valores de São Paulo (BOVESPA), reforçando a sua representatividade.

\begin{tabular}{|l|l|l|}
\hline \multicolumn{1}{|c|}{ CEARÁ } & \multicolumn{1}{|c|}{ RIO GRANDE DO SUL } & \multicolumn{1}{c|}{ SÃO PAULO } \\
\hline 1 - Dakota Nordeste S/A & 1 - Calçados Andreza S/A & 1 - Calçados Sândalo S/A \\
\hline 2 - Dilly Nordeste S/A & 2 - Calçados Azaléia S/A & 2 - Cambuci S/A \\
\hline 3 - Vulcabrás do Nordeste S/A & 3 - Calçados Beira Rio S/A & 3 - São Paulo Alpargatas S/A \\
\hline & 4 - Calçados Fillis S/A & 4 - Vulcabrás S/A \\
\hline & 5 - Calçados Jacob S/A & \\
\hline & 6 - Daiby S/A & \\
\hline & 7 - Dakota S/A & \\
\hline & 8 - Grendene S/A & \\
& &
\end{tabular}

Quadro 3: Amostra selecionada

Não obstante a representatividade econômica da amostra (26\% do faturamento setorial em 2006), destaca-se que a utilização de maior quantidade de empresas ficou prejudicada pela não obrigatoriedade de publicação das demonstrações contábeis por 
parcela significativa delas. Tal não obrigatoriedade deve-se a dois aspectos principais: (1) predominância de empresas constituídas sob a forma de sociedades por quotas de responsabilidade limitada - Ltda; (2) prevalência da categoria "fechada" entre aquelas empresas constituídas como sociedade anônima.

A pesquisa, realizada no período de setembro de 2006 a maio de 2007, contemplou publicações dos meses de março a maio dos anos de 1998 a 2007 no portal do Diário Oficial do Estado do Rio Grande do Sul (CORAG, 2006-2007), Diário Oficial do Estado de São Paulo (IMPRENSA OFICIAL, 2006-2007), Diário Oficial do Estado do Ceará (SEPLAG, 2006-2007) e Bolsa de Valores de São Paulo (BOVESPA, 2006-2007).

\subsection{PROCEDIMENTOS METODOLÓGICOS}

Tendo em vista a quantidade de empresas e dados pesquisados, e dadas as limitações de espaço para desenvolvimento do estudo, optou-se pela estratégia de apresentação dos dados do conjunto das empresas, na forma de índices-padrão. 0 resultado da análise das empresas, de forma individual, concentrou-se na elaboração do ranking em todos os anos pesquisados.

Para tanto, depois de concluída a coleta dos dados, as demonstrações contábeis foram padronizadas, resumindo-se esse processo no seguinte: (1) apresentação dos valores em milhares de Reais; (2) contas redutoras do ativo circulante (duplicatas descontadas) foram reclassificadas para a conta empréstimos e financiamentos no passivo circulante; (3) ativos e passivos circulantes foram separados em financeiros e operacionais; (4) ativos e passivos de longo prazo, pelo número reduzido de contas, não foi individualizado; (5) quando o valor do passivo esteve maior que o valor do ativo, o resultado foi denominado de passivo a descoberto, substituindo-se a expressão patrimônio líquido por esta denominação (CFC, 2005); (6) na demonstração do resultado do exercício as contas foram reclassificadas em operacionais, financeiras, outras contas (equivalência patrimonial e juros remuneratórios sobre o capital próprio) e não operacionais.

A partir das demonstrações contábeis padronizadas foram calculados os indicadores econômico-financeiros (Quadro 4) por empresa e por ano. A definição dos indicadores utilizados baseou-se na necessidade de explicação das possíveis causas e efeitos do comportamento econômico-financeiro das empresas, evidenciado pelas análises.

Para o cálculo dos indicadores que utilizam valores médios procedeu-se a atualização dos valores nominais de anos anteriores para uma mesma data base. Para tanto, utilizou-se os índices de variação do IPCA - IBGE, acumulado 12 meses. Em relação ao cálculo do indicador Valor Econômico Agregado, definiu-se a taxa SELIC (média diária de juros) anualizada com base em 252 dias úteis (BACEN, 2008), como sendo o custo de oportunidade.

Depois de calculados os indicadores econômico-financeiros, aplicou-se, para cada empresa, o modelo de previsão de insolvência desenvolvido por Brito e Assaf Neto (2001). Neste modelo, o ponto de corte é 0,5 , classificando-se as empresas com resultado inferior a esse índice como solventes e as empresas com resultado superior como insolventes. 


\begin{tabular}{|c|c|c|}
\hline Grupo & Indicador & Fórmula \\
\hline \multirow{3}{*}{ Liquidez } & Liquidez corrente & Ativo circulante $\div$ Passivo circulante \\
\hline & Liquidez geral & $\begin{array}{l}\text { (Ativo circulante }+ \text { Ativo realizável a longo prazo }) \div \\
(\text { Passivo circulante }+ \text { Exigível a longo prazo })\end{array}$ \\
\hline & Variação do estoque de Liquidez & $\begin{array}{l}\text { (Variação do disponível +Variação aplicações financeiras) } \div \\
\text { Ativo total médio }\end{array}$ \\
\hline \multirow{2}{*}{ Atividade } & Prazo médio de estocagem & $\begin{array}{l}\text { (Estoque médio } \div \text { Custo dos produtos vendidos) } \mathrm{x} \text { dias do } \\
\text { período }\end{array}$ \\
\hline & Prazo médio de recebimento & $\begin{array}{l}\text { (Duplicatas a receber média } \div \text { Vendas brutas) } \mathrm{x} \text { dias do } \\
\text { período }\end{array}$ \\
\hline \multirow{3}{*}{ Lucratividade } & Margem bruta & Lucro bruto $\div$ Vendas líquidas \\
\hline & Margem líquida & Lucro Líquido $\div$ Vendas líquidas \\
\hline & Margem operacional & Resultado operacional bruto $\div$ Vendas líquidas \\
\hline \multirow{4}{*}{ Rentabilidade } & Retorno sobre o ativo & Resultado operacional bruto $\div$ Ativo operacional médio \\
\hline & Retorno sobre o patrimônio líquido & Resultado operacional bruto $\div$ Patrimônio líquido médio \\
\hline & Valor econômico agregado & $\begin{array}{l}\text { Resultado operacional bruto - (Custo de oportunidade x } \\
\text { Patrimônio líquido médio) }\end{array}$ \\
\hline & Índice de desempenho empresarial & $\begin{array}{l}\text { (Retorno sobre patrimônio líquido }+ \text { Retorno sobre vendas }+ \\
\text { Retorno sobre ativo) } \div 3\end{array}$ \\
\hline \multirow{3}{*}{ EBITDA } & Cash flow & EBITDA $\div$ Ativo total médio \\
\hline & Margem do EBITDA & EBITDA $\div$ Vendas líquidas \\
\hline & Índice de cobertura de juros & EBITDA $\div$ Despesas financeiras \\
\hline \multirow{3}{*}{ Endividamento } & Composição do endividamento & Passivo circulante $\div$ Passivo exigível total \\
\hline & Dependência financeira & Passivo exigível total $\div$ Ativo total \\
\hline & Participação do capital de terceiros & Passivo exigível total $\div$ Patrimônio líquido \\
\hline \multirow{3}{*}{ Estrutura } & Giro do ativo & Vendas líquidas $\div$ Ativo operacional médio \\
\hline & Imobilização do patrimônio líquido & Ativo permanente $\div$ Patrimônio líquido \\
\hline & Imobilização dos recursos não correntes & $\begin{array}{l}\text { Ativo permanente } \div \text { (Patrimônio líquido }+ \text { passivo exigível a } \\
\text { longo prazo) }\end{array}$ \\
\hline \multirow{3}{*}{ Alavancagem } & Grau de alavancagem financeira & Retorno sobre o patrimônio líquido $\div$ Retorno sobre o ativo \\
\hline & Grau de alavancagem operacional & Variação no lucro operacional $\div$ Variação nas vendas \\
\hline & Grau de alavancagem total & $\begin{array}{l}\text { Grau de alavancagem financeira } x \text { Grau de alavancagem } \\
\text { operacional }\end{array}$ \\
\hline \multirow{6}{*}{$\begin{array}{c}\text { Demais } \\
\text { indicadores }\end{array}$} & Coeficiente de overtrading & Vendas $\div$ Capital circulante líquido \\
\hline & Capital de giro & $\begin{array}{l}\text { (Ativo circulante operacional }- \text { Passivo circulante } \\
\text { operacional) } \div \text { Ativo total }\end{array}$ \\
\hline & Taxa de crescimento sustentável & $\begin{array}{l}\text { Retorno sobre o patrimônio líquido x (Lucro retido } \div \text { Lucro } \\
\text { líquido) }\end{array}$ \\
\hline & Previsão de insolvência & Modelo de Brito e Assaf Neto \\
\hline & Efeito tesoura & Capital circulante líquido - Necessidade de capital de giro \\
\hline & Índice de cobertura dos juros & Resultado operacional bruto $\div$ despesas financeiras x 100 \\
\hline
\end{tabular}

Quadro 4: Indicadores econômico-financeiros 
Dos dados representativos de cada elemento do conjunto de indicadores, foram extraídos os valores da mediana (número central) e dos quartis.

Seguindo as orientações de Vertes e Würch (1986), os mesmos sugerem que num conjunto de empresas sejam estabelecidos coeficientes médios característicos para determinado período (valores típicos ou ratios), evitando possíveis distorções do índicepadrão dos indicadores calculados. 0 valor típico resulta da média aritmética simples das quatro médias a seguir: média aritmética simples, média aritmética ponderada, moda e mediana dos indicadores. A moda foi excluída do cálculo nos casos em que se apresentou de forma indefinida.

Para a análise do conjunto de empresas pesquisadas, classificaram-se os indicadores econômico-financeiros de cada empresa em cada ano em seus respectivos quartis. $\mathrm{Na}$ seqüência, partiu-se para a análise baseada no índice-padrão, definido pela mediana dos dados, de cada grupo de indicadores, efetuando-se também a comparabilidade entre os indicadores de cada empresa com o conjunto.

Como complemento à análise dos índices-padrão, verificou-se a existência de possíveis distorções comparando-os aos respectivos valores típicos. Além disso, cada grupo de indicadores foi submetido ao teste da análise de correlação em relação aos demais, ao nível de significância de $1 \%$.

Elaborou-se, também, o ranking das empresas, partindo-se da metodologia adotada pela revista Melhores e Maiores (EXAME, 2007), a qual utiliza 6 indicadores econômicofinanceiros para compor o índice excelência empresarial. Para os fins desse estudo, o indicador riqueza gerada por empregado foi eliminado da composição do índice, pois não há, nas demonstrações contábeis publicadas, informações sobre o número de empregados. A Tabela 1 apresenta os indicadores e respectivos pesos utilizados.

Tabela 1: Métricas e Pesos para ranking das empresas

\begin{tabular}{|c|c|}
\hline Indicador & Peso final \\
\hline Crescimento em vendas & 12 \\
\hline Investimento no imobilizado & 18 \\
\hline Liderança de mercado & 18 \\
\hline Liquidez corrente & 23 \\
\hline Rentabilidade do patrimônio & 29 \\
\hline Total dos pesos & $\mathbf{1 0 0}$ \\
\hline
\end{tabular}

Fonte: elaboração própria a partir da revista Exame (2007)

Os pontos conferidos às empresas com melhor desempenho foram: 15 pontos para a melhor colocada, 14 para a segunda, e assim sucessivamente, até que a décima quinta tenha ficado com um ponto. Os pontos são atribuídos somente às empresas que apresentam indicadores positivos. Da multiplicação dos pontos pelo peso atribuído a cada indicador resulta o ranking anual das empresas. 0 ranking final das empresas, referente ao total de períodos analisados, é produto da soma das posições das empresas no ranking anual.

\subsection{LIMITAÇÕES DO MÉTODO}

As informações geradas pela análise das demonstrações contábeis possuem limitações que precisam ser compreendidas pelos diversos usuários interessados, para não 
gerar falsa expectativa além das reais possibilidades de êxito dessa técnica nos processos de análise.

Sobre isso, Saporito (2005) destaca as seguintes limitações relacionadas: (1) à inflação; (2) à confiabilidade das informações publicadas; (3) à defasagem temporal das informações. Em relação aos efeitos da inflação, limita-se este estudo à atualização de valores para uma mesma data base por meio de índices anualizados coincidentes com a data das demonstrações contábeis. Outra limitação está na apresentação das contas pelo valor total do grupo, podendo distorcer o resultado apurado para alguns indicadores, como, por exemplo, o prazo médio de estocagem, cujos valores de produtos acabados e matérias-primas não constam na maioria das demonstrações contábeis.

Os dados contábeis são sensíveis, também, a problemas relacionados com as evidências geradas pela análise de correlação, visto que o uso do método das partidas dobradas faz com que a maioria das informações contábeis sejam correlacionadas entre si, ao passo que a correlação não implica causalidade em algum sentido (SOUZA; ZANELLA; NASCIMENTO, 2005).

As limitações ocorrem também pelo tamanho da amostra e pela utilização de uma amostragem não probabilística, que impossibilita generalizar os resultados encontrados como sendo o comportamento do setor ou de outras empresas não pesquisadas.

Quanto ao método de classificação das empresas utilizado pela publicação Exame Melhores e Maiores, apesar de o resultado ser uma referência, não é possível afirmar que a empresa melhor classificada obteve também o melhor desempenho, tendo em vista utilizar somente seis indicadores, os quais não são unanimidade entre as publicações semelhantes.

\section{APRESENTAÇÃO E ANÁLISE DOS DADOS}

\subsection{ANÁLISE DO GRUPO DE EMPRESAS}

A análise do índice-padrão de cada indicador, ao comparar a evolução dos indicadores, principalmente do ano 2000 em relação ao ano de 2006, revela que houve:

- estabilidade da liquidez corrente $(R \$ 2,2)$ e liquidez geral (de $R \$ 1,8$ para $R \$ 1,9)$ e redução na variação do estoque de liquidez (de 1,2\% para 0\%). Verifica-se, assim, que os indicadores de liquidez permaneceram praticamente inalterados, e que os índices de variação no estoque de disponibilidades pressupõem que não houve restrições ao crédito em algum período;

- aumento do prazo médio de estocagem em 9 dias e de recebimento em 23 dias, demonstrando tendência de aumento dos níveis de estoque e do saldo de clientes de forma desproporcional às vendas;

- redução da margem bruta (de $27 \%$ para $21 \%$ ) e operacional (de 5,3\% para 0\%) e aumento da margem líquida (de 2,6\% para 6,1\%), evidenciando que a redução da lucratividade operacional foi compensada por ganhos financeiros ou oriundos de outros investimentos (equivalência patrimonial e aplicações financeiras) realizados pelas empresas;

- redução das margens de rentabilidade (índice de desempenho empresarial de $12 \%$ para 3,6\%; retorno sobre o ativo de $8,2 \%$ para $1,3 \%$; retorno sobre o patrimônio líquido de 21,6\% para 1,3\%; valor econômico agregado de \$ 846 para $-\$ 5.514)$, em virtude da redução da margem operacional; 
- redução da margem do EBITDA (de 8,2\% para 4,0\%), do cash flow (de 9,2\% para $1,5 \%$ ) e do índice de cobertura de juros - EBITDA (de 96,7\% para 86,1\%), também afetados pela redução da margem operacional;

- aumento do endividamento de curto prazo (de 70,9\% para 71,9\%), estabilidade da participação do capital de terceiros (de $56,2 \%$ para 55,9\%) como contrapartida da redução da dependência financeira (de $41,3 \%$ para $37,4 \%$ ), o que demonstra o aumento dos recursos de terceiros em relação ao capital próprio, mas não em relação ao ativo total da empresa. Esse fato se explica, em parte, pelo aumento da imobilização de recursos não correntes e pela redução do lucro operacional;

- redução do giro do ativo (de 1,8 para 1,3 vez por ano), ou seja, o ativo reduziu o giro pelas vendas, passando de 200 para 277 dias, uma piora de 38,5\%. Houve, também, aumento da imobilização do patrimônio líquido (de 39,9\% para 41,5\%) e estabilidade da imobilização dos recursos não correntes (de $32,9 \%$ para $33 \%$ ), indicando aumento da aplicação de recursos em bens do imobilizado, porém insuficientes para fomentar as vendas, ou ainda em estágio de instalação e desenvolvimento;

* redução do grau de alavancagem financeira (de 1,4 para 1,0$)$ e redução do grau de alavancagem operacional e total (de -0,4 para -2,4), mostrando ausência de alavancagem pela geração de lucros operacionais e de alavancagem financeira;

- redução do coeficiente de overtrading (de 2,8 para 2,3), capital de giro (de 44,7\% para $29,5 \%$ ), previsão de insolvência (de $-4,7$ para $-10,2$ ) e taxa de crescimento sustentável (de $2 \%$ para $0 \%$ ), índice de cobertura de juros (de $81 \%$ para $30,5 \%$ ) e aumento do indicador do efeito tesoura (de \$-194 para \$1.177), ou seja, houve melhora em relação a solvência das empresas (coeficiente de overtrading, previsão de insolvência, efeito tesoura) ao mesmo tempo em que houve queda no capital de giro e na taxa de crescimento pela retenção de recursos próprios.

Observa-se, ainda, pela análise do índice-padrão, do ano 2006 em relação ao ano de 2000 , que a relação entre liquidez, rentabilidade e endividamento em parte confirma a teoria, pois a manutenção dos indicadores de liquidez esteve associada à redução da dependência de recursos de terceiros e da rentabilidade em $46 \%$ da amostra. Das empresas analisadas, 33\% apresentam aumento de liquidez, redução da margem operacional e redução da dependência financeira; $13 \%$ apresentam redução da liquidez e aumento da margem operacional e da dependência financeira; as demais empresas apresentaram situações diferenciadas.

A relação entre o indicador do efeito tesoura, que significa o que a empresa tem de capital circulante líquido para suprir sua necessidade de capital de giro, além do endividamento de curto prazo e imobilização de recursos próprios, embora não se apresente com maior clareza pela análise dos índices-padrão (houve aumento do endividamento de curto prazo), também emerge das análises.

No período examinado, $40 \%$ das empresas reduziram seu endividamento de curto prazo, ao mesmo tempo em que também reduziram o nível de imobilização dos recursos próprios, e mostraram aumento da sobra de capital circulante líquido em relação à necessidade de capital de giro, sendo que em $20 \%$ ocorreu o efeito inverso. Há ainda $20 \%$ delas que aumentaram o endividamento de curto prazo e a necessidade de capital de giro, enquanto reduziram a aplicação de recursos próprios em imobilizações, compensados pelo aumento do uso de recursos de terceiros de longo prazo.

A análise revelou, ainda, diferentes tendências de desempenho econômicofinanceiro das empresas para um mesmo período examinado, o que não permitiu vincular tal desempenho com a situação econômico-financeira vivida pelo setor ou identificar 
características comuns das empresas que expliquem tal comportamento. Por exemplo, enquanto os indicadores de liquidez corrente da Andreza cresceram de 2000 a 2006, os da Azaléia decresceram e os da Beira Rio ora cresceram, ora decresceram. Já os de liquidez geral apresentaram crescimento ou decréscimo alternado ano a ano.

Além disso, a ausência de informações sobre a parcela da receita de vendas formada por exportações e por vendas no mercado nacional impossibilita uma análise mais efetiva do desempenho das organizações. Ficaram prejudicadas, por exemplo, a correlação e a análise da influência das taxas de câmbio no resultado das empresas, assim como a segregação da lucratividade de acordo com as vendas para o mercado externo e para o mercado interno. Isso revela deficiências no disclosure apresentado pelas demonstrações contábeis das mesmas.

\subsection{APLICAÇÃO DA ANÁLISE DE CORRELAÇÃO AOS INDICADORES}

Análise de correlação foi aplicada aos índices-padrão dos indicadores, com exceção do índice de excelência empresarial, destinado ao ranking das empresas, mais o índice de previsão de insolvência. Os resultados da análise, num total de 435 coeficientes, apontam para $58,6 \%$ de correlações positivas, $40,7 \%$ de correlações inversas e $0,7 \%$ de correlações nulas, conforme revelado no Quadro 5 . Verifica-se também que as correlações positivas e inversas classificadas como baixas ou médias representam $57,5 \%$ dos coeficientes (Quadro $5)$.

\begin{tabular}{|c|c|c|c|c|c|c|}
\hline \multicolumn{3}{|c|}{ Correlação positiva } & \multirow{8}{*}{$\mathbf{X}$} & \multicolumn{3}{|c|}{ Correlação inversa } \\
\hline Classificação & Intervalo & Quantidade & & Quantidade & Intervalo & Classificação \\
\hline Perfeita & 1,00 & 1 & & Nenhuma & $-1,00$ & Perfeita \\
\hline Muito alta & 0,90 a 0,99 & 7 & & 2 & $-0,90$ a $-0,99$ & Muito alta \\
\hline Alta & 0,70 a 0,89 & 36 & & 19 & $-0,70$ a $-0,89$ & Alta \\
\hline Média & 0,40 a 0,69 & 75 & & 46 & $-0,40$ a $-0,69$ & Média \\
\hline Baixa & 0,01 a 0,39 & 136 & & 110 & $-0,01$ a $-0,39$ & Baixa \\
\hline \multicolumn{2}{|c|}{ Total } & 255 & & 177 & \multicolumn{2}{|c|}{ Total } \\
\hline Nula & 0,00 & 3 & & & & \\
\hline
\end{tabular}

Quadro 5: Comparativo dos resultados das correlações positivas e inversas dos índicespadrão do período 2000 a 2006.

Ao nível de confiança de $99 \%$, foram confirmados $45 \%$ dos coeficientes e rejeitados $55 \%$ deles. Por exemplo, o teste entre o índice de liquidez geral e o índice de dependência financeira, retornou um intervalo de 0,49, confirmando a correlação que resultou em 0,75. As correlações nulas foram rejeitadas. Não houve correlação inversa perfeita e a única positiva perfeita foi confirmada, ratificando a correlação entre cash flow e retorno sobre o ativo, tendo ambos os índices (resultado operacional e o ativo operacional) consistentes ao cálculo.

A correlação entre índices de liquidez, rentabilidade e endividamento reafirmaram a análise, visto que a liquidez geral apresenta correlação inversa alta com índices de lucratividade (margem bruta; margem operacional), rentabilidade (índice de desempenho empresarial; retorno sobre o ativo) e dependência financeira (dependência financeira, participação do capital de terceiros), ou seja, pode-se afirmar, pela análise, que quanto maior a liquidez, menor a rentabilidade e o endividamento. Ratifica, também, as correlações do efeito tesoura (capital circulante líquido ante a necessidade de capital de giro), pois, à medida que este índice aumenta, aumenta também a liquidez e reduz a lucratividade e rentabilidade, bem como a dependência financeira em coeficientes de correlação médios e altos. 
No grupo de indicadores de lucratividade, nota-se alta correlação entre as margens operacional e bruta, baixa correlação entre as margens, operacional e líquida, e correlação inversa média entre as margens bruta e líquida. Estas últimas correlações evidenciam a influência do resultado financeiro e não operacional, bem como da equivalência patrimonial no resultado do exercício, distinguindo-o do resultado operacional.

A análise de correlação evidencia, também, a falta de clareza nas relações entre o indicador efeito tesoura, endividamento de curto prazo e imobilização de recursos próprios, pois o índice-padrão demonstra que, à medida que o capital circulante líquido torna-se em excesso à necessidade de capital de giro, há um crescimento da imobilização de recursos próprios e uma baixa redução do endividamento de curto prazo, evidenciando divergências com a análise individualizada das empresas.

Ainda em relação à lucratividade, verifica-se que os indicadores do EBITDA correlacionam-se inversamente com o endividamento de curto prazo e com os índices de imobilização, porém de forma positiva com o endividamento em geral. Já os índices de imobilização correlacionam-se também de forma inversa com o grau de alavancagem operacional, denotando que a aplicação de recursos em ativo fixo reduz a lucratividade da operação.

Pela análise de correlação, assim como na análise por grupo de indicadores, evidencia-se que, além dos fatores apontados pela teoria como, por exemplo, a relação liquidez, rentabilidade e endividamento ou, ainda, capital circulante líquido, endividamento e imobilizações de recursos próprios, as empresas possuem particularidades inerentes ao processo de gestão. Reforça-se que, em decorrência das limitações no uso de simples correlações entre variáveis, é indicado o uso de ferramentas estatísticas que verifiquem a relação causal entre elas. Porém, dadas as limitações de dados e ao escopo desta pesquisa, tal verificação não foi realizada.

\subsection{CLASSIFICAÇÃO DAS EMPRESAS}

Para a elaboração do ranking de empresas, Dakota e Vulcabrás do Nordeste, por não terem informações sobre as vendas do ano de 1999, não pontuaram no item crescimento em vendas do ano 2000. Quanto ao quesito investimentos no imobilizado, está considerado o montante nominal que cada empresa investiu no ano, sem observar a relação destes valores com o porte da empresa. Na apuração da liderança de mercado, a classificação das empresas se dá em relação às vendas totais do grupo das pesquisadas.

Da análise por critério de classificação, as seguintes observações são destacadas:

- São Paulo Alpargatas lidera em investimentos no imobilizado e em liderança de mercado, podendo-se deduzir que a estrutura fabril recebeu investimentos para mantê-la como a empresa de maior valor em vendas;

- Dilly Nordeste lidera o crescimento em vendas e o retorno sobre o patrimônio líquido, pressupondo-se que o aumento em vendas refletiu positivamente no aumento do seu lucro operacional;

- Calçados Jacob lidera em liquidez corrente, porém nos demais indicadores situa-se entre a $12^{\mathrm{a}}$ e $15^{\mathrm{a}}$ colocações, reforçando que a opção por maior segurança induz a empresa a menor lucratividade e rentabilidade, bem como estabilidade no nível das atividades operacionais.

No critério crescimento em vendas, a empresa líder, Dilly Nordeste, cresceu aproximadamente $648 \%$ comparando-se as vendas do ano de 2006 em relação às do ano 2000, sendo a única empresa que apresentou crescimento em todos os períodos. Quanto à 
empresa Jacob, última colocada, houve redução nas suas vendas, próximo a $72 \%$, comparando-se os mesmos períodos.

Em relação ao critério investimento no imobilizado, a empresa líder foi a São Paulo Alpargatas, com investimentos superiores a R\$ 260 milhões no período de 2000 a 2006 . A segunda empresa colocada, Vulcabrás do Nordeste, investiu próximo a R\$100 milhões; e a última colocada, Vulcabrás, investiu próximo a R\$ 230 mil, ressalvando-se que se trata de uma empresa controladora de baixa atividade operacional própria. Destacam-se, também, os investimentos da Grendene, cujo montante ficou próximo a R\$ 200 milhões.

Com vendas líquidas acima de R\$ 6,7 bilhões, referente ao valor acumulado do período de 2000 a 2006, a São Paulo Alpargatas também conquistou a primeira colocação no indicador líder de mercado. Suas vendas representam aproximadamente $28 \%$ do valor acumulado do grupo de empresas pesquisadas no mesmo período. Outras empresas que se destacam por terem valor acumulado de vendas líquidas, no mesmo período, superior a $\mathrm{R} \$$ 1 bilhão são: Grendene (R\$ 4,2 bilhões), Azaléia (R\$ 3,9 bilhões), Vulcabrás e Beira Rio (R\$ 1,8 bilhão cada empresa), e Dakota Nordeste (R\$ 1,4 bilhão). A utilização das vendas líquidas e não das vendas brutas para o cálculo do indicador de liderança de mercado procura eliminar a influência dos impostos incidentes sobre as vendas no mercado interno, ante a não incidência nas vendas ao externo, visto que as empresas participam de ambos os mercados, porém, em diferentes proporções.

No que tange ao indicador liquidez corrente, a liderança ficou com a empresa Calçados Jacob que, aparentemente, optou por maior segurança e menor exposição ao risco da atividade. Com indicador que cresce de $R \$ 4,2$ (ano de 2000) para $R \$ 26,5$ (ano de 2006), com exceção da Grendene, que no ano de 2000 apresentou um indicador de liquidez corrente de $R \$ 12,4$, as empresas com maior liquidez não ultrapassaram o indicador de $R \$$ 10 de ativo circulante para cada $R \$ 1$ de passivo circulante, destacando-se, além da Grendene, as empresas Dakota e Daiby. Já a empresa Cambuci, última colocada entre as empresas, não apresenta liquidez corrente positiva (acima de $R \$ 1,00$ ), ou seja, seu passivo circulante é maior que o ativo circulante em todos os períodos examinados.

Em relação ao retorno sobre o patrimônio líquido, a liderança da Dilly Nordeste, que também lidera o crescimento em vendas, pressupõe-se que estas, por evoluírem mais do que os custos, propiciaram o aumento do lucro operacional. Acompanhada da Dakota Nordeste e São Paulo Alpargatas, a Dilly Nordeste forma o conjunto de três empresas que apresentaram retorno maior que zero em todos os períodos examinados. As demais empresas apresentaram ora retorno positivo, ora retorno nulo ou negativo, significando prejuízo operacional no exercício.

Quanto à classificação geral, exceto nos anos de 2005 e 2006 em relação à empresa líder e nos anos de 2000, 2001, 2003, 2004 e 2005 em relação à última colocada, houve grande volatilidade no posicionamento das empresas, conforme demonstrado na Tabela 2. 
Tabela 2: Classificação geral das empresas por ano.

\begin{tabular}{|c|c|c|c|c|c|c|c|}
\hline Empresa & 2006 & 2005 & 2004 & 2003 & 2002 & 2001 & 2000 \\
\hline Calçados Andreza S/A & $14^{\circ}$ & $12^{\circ}$ & $7^{\circ}$ & $6^{\circ}$ & $5^{\circ}$ & $2^{\circ}$ & $7^{\circ}$ \\
\hline Calçados Azaléia S/A & $10^{\circ}$ & $9^{\circ}$ & $12^{\circ}$ & $13^{\circ}$ & $12^{\circ}$ & $9^{\circ}$ & $8^{\circ}$ \\
\hline Calçados Beira Rio S/A & $3^{\circ}$ & $3^{\circ}$ & $6^{\circ}$ & $9^{\circ}$ & $11^{\circ}$ & $4^{\circ}$ & $1^{\circ}$ \\
\hline Dilly Nordeste S/A & $6^{\circ}$ & $4^{\circ}$ & $3^{\circ}$ & $3^{\circ}$ & $3^{\circ}$ & $1^{\circ}$ & $2^{\circ}$ \\
\hline Calçados Fillis S/A & $12^{\circ}$ & $13^{\circ}$ & $14^{\circ}$ & $11^{\circ}$ & $6^{\circ}$ & $5^{\circ}$ & $11^{\circ}$ \\
\hline Calçados Jacob S/A & $11^{\circ}$ & $11^{\circ}$ & $13^{\circ}$ & $12^{\circ}$ & $7^{\circ}$ & $8^{\circ}$ & $3^{\circ}$ \\
\hline Calçados Sândalo S/A & $15^{\circ}$ & $14^{\circ}$ & $10^{\circ}$ & $14^{\circ}$ & $10^{\circ}$ & $12^{\circ}$ & $12^{\circ}$ \\
\hline Cambuci S/A & $8^{\circ}$ & $10^{\circ}$ & $11^{\circ}$ & $10^{\circ}$ & $9^{\circ}$ & $13^{\circ}$ & $4^{\circ}$ \\
\hline Daiby S/A & $9^{\circ}$ & $8^{\circ}$ & $5^{\circ}$ & $7^{\circ}$ & $1^{\circ}$ & $3^{\circ}$ & $9^{\circ}$ \\
\hline Dakota S/A & $7^{\circ}$ & $7^{\circ}$ & $8^{\circ}$ & $5^{\circ}$ & $13^{\circ}$ & $11^{\circ}$ & $10^{\circ}$ \\
\hline Dakota Nordeste S/A & $4^{\circ}$ & $6^{\circ}$ & $9^{\circ}$ & $2^{\circ}$ & $2^{\circ}$ & $6^{\circ}$ & $6^{\circ}$ \\
\hline Grendene S/A & $5^{\circ}$ & $2^{\circ}$ & $1^{\circ}$ & $1^{\circ}$ & $15^{\circ}$ & $14^{\circ}$ & $14^{\circ}$ \\
\hline São Paulo Alpargatas S/A & $1^{\circ}$ & $1^{\circ}$ & $4^{\circ}$ & $4^{\circ}$ & $4^{\circ}$ & $7^{\circ}$ & $5^{\circ}$ \\
\hline Vulcabrás S/A & $13^{\circ}$ & $15^{\circ}$ & $15^{\circ}$ & $15^{\circ}$ & $14^{\circ}$ & $15^{\circ}$ & $15^{\circ}$ \\
\hline Vulcabrás do Nordeste S/A & $2^{\circ}$ & $5^{\circ}$ & $2^{\circ}$ & $8^{\circ}$ & $8^{\circ}$ & $10^{\circ}$ & $13^{\circ}$ \\
\hline
\end{tabular}

Na Tabela 3 é apresentada a classificação geral das empresas no período examinado, tendo a empresa Dilly Nordeste conquistado o $1^{\circ}$ lugar, a São Paulo Alpargatas o $2^{\circ}$, e assim sucessivamente, até a última colocada Vulcabrás.

Tabela 3: Classificação geral das empresas.

\begin{tabular}{|c|c|}
\hline Classificação & Nome da empresa \\
\hline $1^{\circ}$ lugar & Dilly Nordeste S/A \\
\hline $2^{\circ}$ lugar & São Paulo Alpargatas S/A \\
\hline $3^{\circ}$ lugar & Dakota Nordeste S/A \\
\hline $4^{\circ}$ lugar & Calçados Beira Rio S/A \\
\hline $5^{\circ}$ lugar & Daiby S/A \\
\hline $6^{\circ}$ lugar & Vulcabrás Nordeste S/A \\
\hline $7^{\circ}$ lugar & Grendene S/A \\
\hline $8^{\circ}$ lugar & Calçados Andreza S/A \\
\hline $9^{\circ}$ lugar & Dakota S/A \\
\hline $10^{\circ}$ lugar & Calçados Jacob S/A \\
\hline $11^{\circ}$ lugar & Cambuci S/A \\
\hline $12^{\circ}$ lugar & Calçados Fillis S/A \\
\hline $13^{\circ}$ lugar & Calçados Azaléia S/A \\
\hline $14^{\circ}$ lugar & Calçados Sândalo S/A \\
\hline $15^{\circ}$ lugar & Vulcabrás S/A \\
\hline
\end{tabular}

Dilly Nordeste e São Paulo Alpargatas se destacaram no quesito vendas, quer seja pelo crescimento, quer seja pela liderança de mercado. A primeira causa provável associa o crescimento das vendas ao aumento do lucro operacional; a segunda causa provável vincula-se à renovação e/ou ampliação da sua estrutura fabril.

Há também, por outro lado, um movimento inverso dessas empresas ao longo do período de 2000 a 2006. A São Paulo Alpargatas melhorou seu posicionamento, encerrando 
o ano de 2006 como a líder do ranking, cujo resultado é confirmado pela publicação Exame (2007); enquanto isso, a Dilly Nordeste decresceu, encerrando o ano em $6^{\circ}$ lugar.

\section{CONCLUSÃO}

Conforme planejado, foram calculados os índices-padrão do grupo de empresas analisadas. Ainda mediante a utilização da metodologia criada pela publicação Exame Melhores e Maiores, as empresas receberam pontuação para o respectivo ranking, permitindo definir qual a melhor dentre elas, segundo o critério adotado. Atingiu-se, dessa forma, o objetivo do estudo em analisar o desempenho econômico-financeiro de empresas calçadistas brasileiras no período de 2000 a 2006.

No conjunto, as empresas apresentaram basicamente três situações: (1) opção por maior retenção de caixa e conseqüente redução da atividade operacional com redução da rentabilidade; (2) opção por redução da atividade operacional e investimentos no mercado financeiro; (3) opção por investimentos na atividade operacional própria ou das controladas com recursos próprios e/ou de terceiros.

O exame dos indicadores apurados revelou, porém, que não houve períodos de desempenho econômico-financeiro uniforme entre as empresas, influenciados, por exemplo, pelas condições mercadológicas da época, impossibilitando a identificação de características comuns entre as indústrias calçadistas. Mesmo considerando as limitações destacadas, a análise dos indicadores permitiu identificar particularidades do conjunto de empresas por meio dos índices-padrão.

Os resultados da análise dos índices-padrão apontam que durante o período de 2000 a 2006 houve estabilidade nos índices de liquidez e melhora nos índices de solvência. A atividade operacional apresentou redução nas vendas, que, acompanhada de uma redução não proporcional dos custos e despesas operacionais, provavelmente em função dos custos fixos, refletiu na queda da lucratividade e rentabilidade. Essa queda foi acompanhada também pela redução do capital de giro e da capacidade de cobertura dos juros e despesas financeiras. Além disso, houve aumento nos prazos médios de estocagem e recebimento.

Por conseguinte, as empresas apresentaram redução no giro do ativo e estabilidade nos índices de imobilização. Evidencia-se, também, a estagnação das taxas de crescimento com recursos próprios e a ausência de alavancagem operacional. Em contrapartida às perdas na atividade operacional, as empresas recorreram a ganhos no mercado financeiro, os quais somados aos ganhos com equivalência patrimonial e outros resultados não operacionais, compensaram os prejuízos da atividade operacional, propiciando aumentos na margem líquida final.

Os índices de endividamento de curto prazo e de participação do capital de terceiros sobre o capital próprio mostraram-se estáveis.

O ranking demonstrou variações nas posições das empresas entre os períodos, de 2000 à 2006. Empresas situadas nas últimas e primeiras colocações inverteram de posição durante o período, ao passo que outras se alternam entre as posições medianas, comprovando os resultados da análise que indica ausência de desempenho econômicofinanceiro uniforme entre as empresas no período examinado.

A falta de informações sobre a receita de vendas para o mercado externo e para o mercado interno impossibilitou verificar, com maior profundidade, as influências da política cambial e da concorrência no exterior nos resultados das empresas. A análise dos efeitos da valorização da moeda brasileira nos resultados das empresas também ficou 
prejudicada. Esforços em pesquisas mais específicas poderão suprir as limitações aqui apresentadas.

\section{REFERÊNCIAS}

ABICALÇADOS - Associação Brasileira das Indústrias de Calçados. Fabricantes nacionais. Disponível em: <http://www.abicalcados.com.br/index.php?page=pesquisa_fabricantes>. Acesso em 07 mai. 2007.

AQUINO, A. C. B.; TACHIBANA, W. K. Avaliação de desempenho nas empresas de construção civil, como apoio à tomada de decisão. Congresso Brasileiro de Custos, 6. 1999. São Paulo. Anais do VI Congresso Brasileiro de Custos, São Paulo,1999.

ASSAF NETO, A. Estrutura e análise de balanços: um enfoque econômico-financeiro. 8 . ed. São Paulo: Atlas, 2006.

ASSINTECAL. Exportações de calçados chineses para a Europa aumentam quase 10\%. 05 dez. 2007. Disponível em:

<http://www.assintecal.org.br/assintecal/web/imprime_conteudo.asp?codConteudo=2075 0>. Acesso em 06 dez. 2007.

BACEN. Histórico das taxas de juros fixadas pelo Copom e evolução da taxa Selic. Banco Central do Brasil. Disponível em: <http://www.bcb.gov.br/pec/copom/port/taxaselic.asp>. Acesso em 03 abr. 2008.

BALANÇO ANUAL. As melhores empresas brasileiras. São Paulo: Gazeta Mercantil, ano XXIX, n. 29, ago. 2005.

BARBOSA, E.; ALVIM, A. M. As exportações de calçados do Rio Grande do Sul: uma avaliação dos efeitos da política cambial brasileira e dos condicionantes externos no período 2000-2005. Encontro de Economia Gaúcha, 3. 2006. Porto Alegre. Anais do III Encontro de Economia Gaúcha, Pontifícia Universidade Católica do Rio Grande do Sul, Porto Alegre, 2006.

BERTON, L. H. Indicadores de desempenho e as práticas de boa governança corporativa. 2003. 215f. Tese (Doutorado em Engenharia da Produção). Florianópolis: Universidade Federal de Santa Catarina, 2003.

BEUREN, I.M. (Org). Como elaborar trabalhos monográficos em contabilidade. São Paulo, Atlas, 2003.

BNDES. A indústria calçadista no Brasil. Banco Nacional de Desenvolvimento Econômico e Social. Informe setorial, área industrial, Rio de Janeiro, jul. 2006, n.1.

BOVESPA - Bolsa de Valores de São Paulo. Empresas - para investidores - empresas listadas setor de atuação. Disponível em: <http://www.bovespa.com.br/Empresas/InformacoesEmpresas/ExecutaAcaoConsultaSetor Merc.asp?Segmento=Calçados>. Acessos de set. 2006 a mai. 2007.

BRITO, G. A. S.; ASSAF NETO, A. Modelo de classificação de risco de crédito de grandes empresas. Congresso USP de Controladoria e Contabilidade, 5. 2005. São Paulo. Anais do $5^{\circ}$ Congresso USP de Controladoria e Contabilidade, 2005. 
CAETANO, E. Indústria calçadista mineira está otimista com coleção de inverno. ASN Agência SEBRAE de Notícias - DF. 25 fev. 2008. Disponível em: <http://asn.interjornal.com.br/noticia_pdf.kmf?noticia=6990468>. Acesso em 02 abr. 2008.

CARLONI, A. R.; COSTA, A. B. da; GARCIA, R. Setor de calçados: competitividade, mudança tecnológica e organizacional. Brasília: SENAI, 2007.

CARVALHO, D. Dois irmãos contra a China. Portal Exame - Portal EXAME - Negócios Economia Marketing Finanças C. Editora Abril, 2007. Disponível em: <http://portalexame.abril.uol.com.br/revista/exame/edicoes/0898/negocios/m0134338.h tml>. Acesso em 27 jul. 2007.

CASTRO JÚNIOR, F. H. F. Previsão de insolvência de empresas brasileiras usando análise discriminante, regressão logística e redes neurais. 2003. 169f. Dissertação (Mestrado em Administração). Faculdade de Economia, Administração e Contabilidade. São Paulo: Universidade de São Paulo, 2003.

CFC - Conselho Federal de Contabilidade. Resolução CFC n 1.049/05. Brasília: CFC, 2005. CORAG - Companhia Rio-grandense de Artes Gráficas. Diário Oficial da Indústria e Comércio. Diário Oficial do Estado do Rio Grande do Sul. Disponível em: <https://www.corag.com.br/diario/jornal.php?jornal=ind>. Acessos de set. 2006 a mai. 2007.

EXAME. Melhores e Maiores. São Paulo: Abril, edição especial, ago. 2007.

FOLHA ONLINE. Alpargatas compra Dupé por R\$ 49,5 milhões. Folha Online, 21 set. 2007. Disponível em: <http://www1.folha.uol.com.br/folha/dinheiro/ult91u330344.shtml>. Acesso em 21 set. 2007.

FORTE, S. H. A. C.; MOREIRA, M. Z. Internacionalização das maiores empresas exportadoras do setor calçadista brasileiro: estudo do perfil, estratégias e desempenho. Encontro da Anpad, 31. 2007. Anais do XXXI Encontro da Anpad. Rio de Janeiro: Enanpad, 2007.

FORTUNE. The 2007 Fortune 500. Disponivel em: <http://money.cnn.com/magazines/fortune/fortune500/2007/>. Acesso em 14 fev. 2008.

GARCIA, R. Relatório setorial final: calçados e insumos. Portal diretório da pesquisa privada. FINEP, 2006. Disponível em:

<http://www.finep.gov.br/PortalDPP/relatorio_setorial_final/relatorio_setorial_final_impr essao.asp?lst_setor=30>. Acesso em $31 \mathrm{dez} .2007$.

GIANISELLA, R. L. C. Alianças estratégicas: um estudo sobre as práticas de controle de gestão adotadas por empresas dos pólos calçadistas do Vale do Rio dos Sinos - RS e de Franca - SP. 2006. 210f. Dissertação (Mestrado em Ciências Contábeis). São Leopoldo: Universidade do Vale do Rio dos Sinos, 2006.

GIL, A. L. Como elaborar projetos de pesquisa. 4.ed. São Paulo, Atlas, 2002.

IMPRENSA OFICIAL - Secretaria de Comunicação do Estado de São Paulo. Caderno Empresarial. Diário Oficial do Estado de São Paulo. Disponível em: <http://balancos.imprensaoficial.com.br/Condiario.asp>. Acessos de set. 2006 a mai. 2007.

IUDÍCIBUS, S.; MARTINS, E.; GELBCKE, E.R. Manual de contabilidade das sociedades por ações: aplicável às demais sociedades. FIPECAFI. 7. ed. São Paulo: Atlas, 2007. 
MÁRIO, P. C. Contribuição ao estudo da solvência empresarial: uma análise de modelos de previsão: estudo exploratório aplicado em empresas mineiras. 2002. $209 \mathrm{f}$. Dissertação (Mestrado em Ciências Contábeis). Faculdade de Economia, Administração e Contabilidade. São Paulo: Universidade de São Paulo, 2002.

MARION, J.C. Análise das Demonstrações Contábeis. Disponível em: <http://www.marion.pro.br/portal/modules/wfdownloads/cap13>. Acesso em 11.03.2008.

MARTIN, R. Do we practice quality principles in the performance measurement of critical success factors? Total Quality Management, v. 8, n. 6, p. 429-444, 1997.

MARTINS, M. A. S. Construção de indicadores para avaliação de desempenho empresarial. 209f. Dissertação (Mestrado em Economia). Faculdade de Ciências Econômicas. Porto Alegre: Universidade Federal do Rio Grande do Sul, 2004.

MATARAZZO, D. C. Análise financeira de balanços: abordagem básica e gerencial. 6.ed. São Paulo: Atlas, 2003.

MIRANDA, L. C.; AZEVEDO, S. G. Indicadores de desempenho gerencial mais utilizados pelos empresários: estudo comparativo Brasil - Portugal. In: Encontro Nacional dos Programas de Pós-graduação em Administração, 24. 2000. Florianópolis. Anais do XXIV Encontro da Anpad, 2000. CD-ROM.

MOSIMANN, C. P.; FISCH, S. Controladoria: Seu papel na administração de empresas. 2. ed. São Paulo: Atlas, 1999.

PEREIRA, C. A. Avaliação de resultados e desempenhos. In: CATELLI, A. (Coord.) Controladoria. Uma abordagem da gestão econômica. São Paulo: Atlas, 1999.

SANTOS, A. M. M.; CORRÊA, A. R.; ALEXIM, F. M. B.; PEIXOTO, G. B. T. Deslocamento de Empresas para os Estados do Ceará e da Bahia: o Caso da Indústria Calçadista. BNDES Setorial, Rio de Janeiro, n. 15, p. 63-82, mar. 2002.

SAPORITO, A. Análise referencial: proposta de um instrumento facilitador da análise a longo prazo de demonstrações contábeis. 2005. 191f. Tese (Doutorado em Ciências Contábeis). Faculdade de Economia, Administração e Contabilidade. São Paulo: Universidade de São Paulo, 2005.

SCHNEIDER, T. M. L. Diagnóstico dos indicadores de avaliação do desempenho empresarial em indústrias calçadistas de grande porte do Vale do Rio dos Sinos. 2003. 136f. Dissertação (Mestrado em Ciências Contábeis). São Leopoldo: Universidade do Vale do Rio dos Sinos, 2003.

SCHUH, G.C. O design como diferencial competitivo: um estudo em pequenas empresas calçadistas do Vale do Rio dos Sinos. 2006. 140f. Dissertação (Mestrado em Administração). São Leopoldo: Universidade do Vale do Rio dos Sinos, 2006.

SEPLAG - Secretaria do Planejamento e Gestão do Estado do Ceará. Diário Oficial do Estado do Ceará. Disponível em: <http://pesquisa.doe.seplag.ce.gov.br/doepesquisa/sead. Acessos: de set. 2006 a mai. 2007.

SILVA, J. P. Análise financeira das empresas. 3.ed. São Paulo: Atlas, 1995.

SOUZA, M. A.; ZANELLA, F. C.; NASCIMENTO, A. M. Utilização do custo-meta por empresas brasileiras como estratégia de gestão: alguns estudos setoriais utilizando o Método da Causalidade de Granger. Revista Contabilidade e Finanças. São Paulo, n. 39, p. 33-46, jan/abr. 2005.

VALOR 1000. Maiores empresas. São Paulo: Valor Econômico, ano 7, n. 7, ago. 2007.

VERTES, A.; WÜRCH, A. W. Estrutura, análise e interpretação de balanços. 8 ed. São Leopoldo: Otomit, 1986. 
VIANA, F. L. E.; ROCHA, R. E. V. A indústria de calçados no Nordeste: características, desafios e oportunidades. (Série Documentos do ETENE, n. 14). Fortaleza: Banco do Nordeste do Brasil, 2006.

ZERO HORA. Crescem as vendas no setor couro-calçados em 2007. Caderno Economia. Ano 44, edição $n^{\circ}$ 15.467, p.33. Porto Alegre: 04 jan. 2008.

\section{ENDEREÇO DOS AUTORES}

Centro de Gestão Organizacional UNIVATES

Rua Avelino Tallini, 171 - Bairro Universitário

Lajeado, RS - Brasil

95900-000

Centro de Ciências Econômicas

Universidade do Vale do Rio dos Sinos

Av. Unisinos, 950 - Cristo Rei

Caixa-Postal 275

Sao Leopoldo, RS - Brasil

93022-000

Instituto de Ciências Econômicas, Administrativas e Contábeis

Universidade Federal do Rio Grande

Av Itália, KM 8, s/ nº, Pavilhão 4 - Campus Carreiros

Rio Grande, RS - Brasil

96203-000 


\section{APÊNDICES}

Apêndice A - Indicadores de Liquidez

\begin{tabular}{|c|c|c|c|c|c|c|c|}
\hline Corrente & 2006 & 2005 & 2004 & 2003 & 2002 & 2001 & 2000 \\
\hline Indice-padrão & 2,20 & 2,40 & 2,30 & 2,00 & 2,10 & 2,60 & 2,20 \\
\hline $\begin{array}{c}\text { Valor típico } \\
\text { Geral }\end{array}$ & 3,20 & 2,90 & 2,80 & 2,70 & 2,10 & 2,60 & 2,50 \\
\hline Indice-padrão & 1,90 & 1,80 & 1,80 & 1,80 & 1,50 & 1,60 & 1,80 \\
\hline $\begin{array}{l}\text { Valor típico } \\
\text { Variação Esto } \\
\text { de Liquidez }\end{array}$ & 2,60 & 2,00 & 2,00 & 1,90 & 1,60 & 1,70 & 2,50 \\
\hline Indice-padrão & - & $0,6 \%$ & - & $-0,9 \%$ & $0,5 \%$ & $0,1 \%$ & $1,2 \%$ \\
\hline Valor típico & $2,2 \%$ & $4,0 \%$ & $0,9 \%$ & $0,4 \%$ & $1,3 \%$ & $-0,7 \%$ & $2,9 \%$ \\
\hline
\end{tabular}

Apêndice B - Indicadores de Atividade

\begin{tabular}{lrrrrrrr}
\hline PM Estocagem & 2006 & 2005 & 2004 & 2003 & 2002 & 2001 & 2000 \\
\hline Indice-padrão & 61 & 67 & 65 & 71 & 69 & 73 & 52 \\
Valor típico & 59 & 63 & 63 & 66 & 65 & 68 & 59 \\
$\quad$ PM Recebto. & & & & & & & \\
\hline Indice-padrão & 76 & 79 & 70 & 78 & 88 & 84 & 56 \\
Valor típico & 96 & 98 & 87 & 92 & 87 & 858 & 68 \\
\hline
\end{tabular}

Apêndice C - Indicadores de Lucratividade

\begin{tabular}{lrrrrrrr}
\hline Margem Bruta & 2006 & 2005 & 2004 & 2003 & 2002 & 2001 & 2000 \\
\hline İndice-padrão & $21,0 \%$ & $24,0 \%$ & $26,0 \%$ & $28,5 \%$ & $27,1 \%$ & $28,0 \%$ & $27,0 \%$ \\
Valor típico & $26,3 \%$ & $26,2 \%$ & $28,5 \%$ & $28,6 \%$ & $27,6 \%$ & $27,8 \%$ & $28,2 \%$ \\
Marg. Operac. & & & & & & & \\
\hline Indice-padrão & - & $2,0 \%$ & $5,1 \%$ & $3,7 \%$ & $6,9 \%$ & $8,0 \%$ & $5,3 \%$ \\
Valor típico & $4,0 \%$ & $4,6 \%$ & $6,3 \%$ & $5,7 \%$ & $7,3 \%$ & $8,3 \%$ & $7,2 \%$ \\
Marg. Líquida & & & & & & & \\
\hline Indice-padrão & $6,1 \%$ & $1,9 \%$ & $3,1 \%$ & $0,5 \%$ & $5,7 \%$ & $4,6 \%$ & $2,6 \%$ \\
Valor típico & $6,7 \%$ & $4,4 \%$ & $3,3 \%$ & $5,1 \%$ & $2,5 \%$ & $4,3 \%$ & $4,3 \%$ \\
\hline
\end{tabular}

Apêndice D - Indicadores de Rentabilidade e Retorno

\begin{tabular}{lrrrrrrr}
\hline Retor. s/Ativo & 2006 & 2005 & 2004 & 2003 & 2002 & 2001 & 2000 \\
\hline Indice-padrão & $1,3 \%$ & $3,2 \%$ & $5,7 \%$ & $5,7 \%$ & $9,6 \%$ & $12,8 \%$ & $8,2 \%$ \\
Valor típico & $7,1 \%$ & $5,9 \%$ & $6,2 \%$ & $10,7 \%$ & $5,7 \%$ & $13,4 \%$ & $8,9 \%$ \\
$\quad$ Retor. s/Pliq. & & & & & & & \\
\hline Indice-padrão & $1,3 \%$ & $4,6 \%$ & $12,8 \%$ & $10,0 \%$ & $14,8 \%$ & $17,4 \%$ & $21,6 \%$ \\
Valor típico & $22,5 \%$ & $19,6 \%$ & $26,7 \%$ & $17,9 \%$ & $16,6 \%$ & $19,8 \%$ & $18,8 \%$ \\
Desem. Empres. & & & & & & & \\
\hline Indice-padrão & $3,6 \%$ & $4,6 \%$ & $9,3 \%$ & $6,0 \%$ & $17,8 \%$ & $17,3 \%$ & $12,0 \%$ \\
Valor típico & $11,4 \%$ & $10,0 \%$ & $12,3 \%$ & $11,2 \%$ & $7,9 \%$ & $10,8 \%$ & $9,8 \%$ \\
Vlr. Ec. Agreg & & & & & & & -540 \\
\hline Indice-padrão & -5.514 & -7.770 & -2.396 & -4.143 & -2.574 & -560 & 846 \\
Valor típico & -14.874 & -26.668 & -7.647 & -39.798 & -70.811 & -51.978 & -37.034 \\
\hline
\end{tabular}


Apêndice E - Indicadores do EBITDA

\begin{tabular}{lrrrrrrr}
\hline \multicolumn{1}{c}{ Cash Flow } & 2006 & 2005 & 2004 & 2003 & 2002 & 2001 & 2000 \\
\hline Indice-padrão & $1,5 \%$ & $4,1 \%$ & $6,3 \%$ & $6,6 \%$ & $11,7 \%$ & $14,0 \%$ & $9,2 \%$ \\
Valor típico & $6,1 \%$ & $6,7 \%$ & $8,0 \%$ & $11,1 \%$ & $7,4 \%$ & $13,7 \%$ & $9,6 \%$ \\
Margem Ebitda & & & & & & & \\
\hline Indice-padrão & $4,0 \%$ & $4,7 \%$ & $6,7 \%$ & $5,2 \%$ & $13,3 \%$ & $10,4 \%$ & $8,2 \%$ \\
Valor típico & $6,8 \%$ & $6,9 \%$ & $8,1 \%$ & $9,1 \%$ & $10,0 \%$ & $10,2 \%$ & $9,3 \%$ \\
Cob. Jrs Ebitda & & & & & & & \\
\hline Indice-padrão & $86,1 \%$ & $151,5 \%$ & $165,4 \%$ & $233,7 \%$ & $86,1 \%$ & $158,8 \%$ & $96,7 \%$ \\
Valor típico & $165,6 \%$ & $157,6 \%$ & $138,9 \%$ & $260,6 \%$ & $60,8 \%$ & $159,8 \%$ & $157,9 \%$ \\
\hline
\end{tabular}

Apêndice F - Indicadores de Endividamento

\begin{tabular}{lrrrrrrr}
\multicolumn{1}{c}{ Composição } & 2006 & 2005 & 2004 & 2003 & 2002 & 2001 & 2000 \\
\hline Indice-padrão & $71,9 \%$ & $61,1 \%$ & $58,6 \%$ & $59,0 \%$ & $73,4 \%$ & $61,8 \%$ & $70,9 \%$ \\
Valor típico & $74,7 \%$ & $70,1 \%$ & $69,8 \%$ & $68,6 \%$ & $77,8 \%$ & $70,0 \%$ & $75,4 \%$ \\
Depend Financ. & & & & & & & \\
\hline Indice-padrão & $37,4 \%$ & $39,3 \%$ & $37,1 \%$ & $39,5 \%$ & $43,6 \%$ & $40,6 \%$ & $41,3 \%$ \\
Valor típico & $38,3 \%$ & $40,2 \%$ & $41,5 \%$ & $42,8 \%$ & $52,2 \%$ & $43,1 \%$ & $45,4 \%$ \\
Part. Cap. 3o & & & & & & & \\
\hline Indice-padrão & $55,9 \%$ & $63,0 \%$ & $59,0 \%$ & $55,8 \%$ & $65,8 \%$ & $63,1 \%$ & $56,2 \%$ \\
Valor típico & $57,8 \%$ & $61,0 \%$ & $68,5 \%$ & $65,5 \%$ & $69,4 \%$ & $61,2 \%$ & $59,5 \%$ \\
\hline
\end{tabular}

Apêndice G - Indicadores de Estrutura

\begin{tabular}{lrrrrrrr}
\hline Giro do Ativo & 2006 & 2005 & 2004 & 2003 & 2002 & 2001 & 2000 \\
\hline Indice-padrão & 1,3 & 1,3 & 1,4 & 1,4 & 1,4 & 1,4 & 1,8 \\
Valor típico & 1,4 & 1,4 & 1,5 & 1,4 & 1,4 & 1,4 & 1,6 \\
Imob. Pat. Liq. & & & & & & & \\
\hline Indice-padrão & $41,5 \%$ & $45,2 \%$ & $37,5 \%$ & $32,6 \%$ & $31,2 \%$ & $39,5 \%$ & $39,9 \%$ \\
Valor típico & $48,5 \%$ & $51,4 \%$ & $50,5 \%$ & $45,9 \%$ & $52,6 \%$ & $54,3 \%$ & $52,1 \%$ \\
Imob. Rec. NC & & & & & & & \\
\hline Indice-padrão & $33,0 \%$ & $38,8 \%$ & $32,2 \%$ & $29,6 \%$ & $27,0 \%$ & $32,6 \%$ & $32,9 \%$ \\
Valor típico & $54,4 \%$ & $57,3 \%$ & $50,9 \%$ & $50,0 \%$ & $54,2 \%$ & $60,2 \%$ & $61,6 \%$ \\
\hline
\end{tabular}

Apêndice H - Indicadores de Alavancagem

\begin{tabular}{|c|c|c|c|c|c|c|c|}
\hline Alav. Financ. & 2006 & 2005 & 2004 & 2003 & 2002 & 2001 & 2000 \\
\hline İndice-padrão & 1,0 & 1,3 & 1,3 & 1,4 & 1,6 & 1,5 & 1,4 \\
\hline $\begin{array}{l}\text { Valor típico } \\
\text { Alav. Operac. }\end{array}$ & 1,1 & 1,9 & 9,0 & 1,2 & 2,5 & 1,4 & 1,8 \\
\hline İndice-padrão & $-2,4$ & $-6,2$ & 1,9 & $-2,3$ & 0,8 & 3,0 & $-0,4$ \\
\hline $\begin{array}{l}\text { Valor típico } \\
\text { Alav. Total }\end{array}$ & 1,0 & $-6,0$ & 4,0 & 0,6 & 0,9 & $-0,1$ & $-1,0$ \\
\hline Indice-padrão & - & - & 0,1 & - & - & - & - \\
\hline Valor típico & 2,8 & $-7,8$ & $-5,1$ & $-37,6$ & 8,8 & $-0,4$ & $-5,8$ \\
\hline
\end{tabular}


Apêndice I - Outros Indicadores

\begin{tabular}{|c|c|c|c|c|c|c|c|}
\hline Efeito Tesoura & 2006 & 2005 & 2004 & 2003 & 2002 & 2001 & 2000 \\
\hline Indice-padrão & 1.177 & 1 & -345 & -116 & -3.556 & 23 & -194 \\
\hline $\begin{array}{l}\text { Valor típico } \\
\text { Cobert. Jrs. }\end{array}$ & 36.804 & 31.155 & 14.975 & 9.155 & -6.510 & 1.460 & 3.081 \\
\hline İndice-padrão & $30,5 \%$ & $126,1 \%$ & $95,4 \%$ & $150,1 \%$ & $41,0 \%$ & $143,4 \%$ & $81,0 \%$ \\
\hline $\begin{array}{l}\text { Valor típico } \\
\text { Overtrading }\end{array}$ & $77,0 \%$ & $111,7 \%$ & $82,9 \%$ & $182,8 \%$ & $0,3 \%$ & $127,9 \%$ & $120,0 \%$ \\
\hline İndice-padrão & 2,3 & 2,9 & 3,1 & 3,4 & 2,7 & 3,1 & 2,8 \\
\hline $\begin{array}{l}\text { Valor típico } \\
\text { Capital Giro }\end{array}$ & 2,7 & 4,9 & 4,9 & 4,5 & 3,6 & 3,7 & 4,7 \\
\hline İndice-padrão & $29,5 \%$ & $27,9 \%$ & $34,8 \%$ & $29,2 \%$ & $31,3 \%$ & $35,4 \%$ & $44,7 \%$ \\
\hline $\begin{array}{l}\text { Valor típico } \\
\text { Cresc. Sustent. }\end{array}$ & $27,6 \%$ & $27,3 \%$ & $32,8 \%$ & $31,8 \%$ & $28,7 \%$ & $31,2 \%$ & $34,1 \%$ \\
\hline Indice-padrão & - & $0,6 \%$ & $1,0 \%$ & $0,3 \%$ & $0,7 \%$ & $1,1 \%$ & $2,0 \%$ \\
\hline $\begin{array}{l}\text { Valor típico } \\
\text { Prev. Insolvenc. }\end{array}$ & $7,4 \%$ & $5,4 \%$ & $20,6 \%$ & $12,9 \%$ & $28,8 \%$ & $23,2 \%$ & $39,7 \%$ \\
\hline Indice-padrão & $-10,2$ & $-6,1$ & $-8,6$ & $-7,0$ & $-4,7$ & $-7,0$ & $-4,7$ \\
\hline Valor típico & $-9,8$ & $-8,9$ & $-8,4$ & $-7,0$ & $-2,7$ & $-5,6$ & $-3,9$ \\
\hline
\end{tabular}

